\title{
HYBRID EFFECTS OF STIRRUP RATIO AND STEEL FIBERS ON SHEAR BEHAVIOUR OF SELF-COMPACTING CONCRETE
}

\author{
PRAVEEN KANNAM ${ }^{1}$, VENKATESWARA RAO. SARELLA ${ }^{2}$, \\ RATHISH KUMAR PANCHARATHI ${ }^{3}$
}

\begin{abstract}
Shear cracking behaviour of fibrous self-compacting concrete of normal and high strength grade (M30 and M70) is presented here. Two stirrup diameters $(6 \mathrm{~mm} \otimes$ and $8 \mathrm{~mm} \otimes)$ with a constant steel fiber content of $38 \mathrm{~kg} / \mathrm{m}^{3}(0.5 \%$ by volume of concrete) were selected for the present study. The size of the beam was fixed at 100x200x1200mm. The clear span of the beam 1100mm, was maintained throughout the study. A total of 16 shear-deficient beams were tested under three point loading. Two stirrup spacing $(180 \mathrm{~mm}$ and $360 \mathrm{~mm})$ are used for the shear span-to-depth ratio $(\mathrm{a} / \mathrm{d}=2)$. Investigation indicates that initial cracking load and ultimate load increased as the area of shear reinforcement increased by increasing the diameter of stirrup. It was also noted that the failure mode was modified from brittle shear failure to flexural-shear failure in the presence of fibers. The mechanical behaviour of SFRSCC was improved due to the combined effect of stirrups and steel fibers. The stiffness, toughness, and deflection of the beams increased when compared to SCC beams without fibers. The experimental results were compared with existing models available in literature, and the correlation is satisfactory.
\end{abstract}

Keywords: self Compacting Concrete, Shear Failure, Reinforced Concrete (RC), flexural-shear failure.

\footnotetext{
${ }^{1}$ Research Scholar, Department of Civil Engineering, National Institute of Technology, Warangal, India. praveenkcivil@gmail.com ${ }^{2}$ Associate Professor, Department of Civil Engineering, National Institute of Technology, Warangal, India.

${ }^{3}$ Professor, Department of Civil Engineering, National Institute of Technology, Warangal, India.
} 


\section{INTRODUCTION}

When a reinforced concrete beam (RC) is subjected to a combined effect of bending and shear force, beams with lower shear-resisting capacity fail early, even before its full strength is achieved. These types of shear failure are sudden and brittle, as they occur without any warning. To prevent these types of shear failures, beams are reinforced with stirrups. The addition of steel fibers can modify the failure pattern and can also increase shear strength [1]. If a sufficient amount of steel fibers are present in a reinforced concrete member, it can bridge the crack width and can also increase the post-cracking behaviour of the member [2]. Steel fibers can also partially replace stirrups, which can eliminate congestion of reinforcements near beam column joints, thereby reducing the cost of longitudinal reinforcement $[3,4]$. The difference between steel fiber-reinforced self-compacting concrete (SFRSCC) and fiber-reinforced concrete (FRC) is that the addition of steel fibers reduces the fresh properties of self-compacting concrete, whereas inclusions of fibers in fibrous concrete can enhance the post-cracking behaviour. Thus, SFRSCC has the advantages of both SCC and FRC [5]. The key parameters influencing the shear behaviour of reinforced concrete beams are: shear span-to-effective depth ratio $(\mathrm{a} / \mathrm{d})$, grade of concrete $\left(\mathrm{f}_{\mathrm{ck}}\right)$, longitudinal reinforcement $\left(\mathrm{l}_{t}\right)$, area of shear reinforcement $\left(\mathrm{A}_{\mathrm{sv}}\right)$ and volume of fibers $\left(\mathrm{V}_{\mathrm{f}}\right)[6]$. The difference between steel fiber-reinforced self-compacting concrete (SFRSCC) and traditional fiber reinforced concrete (FRC) is that the fiber content of FRC is mainly determined by the post-cracking behaviour, and the fiber content of SFRSCC is mainly restricted by the workability of fresh SCC $[7,8]$. SFRSCC combines the advantages of both SCC and FRC. However, research on the study of SFRSCC beams, especially on the shear behaviour of SFRSCC, is still limited.

The present study shows the experimental results conducted on SFRSCC beams. The main objective of this study is to understand the shear behaviour of SFRSCC beams for different stirrup diameters and spacing for both lower and higher concrete grades (M30 \& M70), and also to analyze the influence of steel fibers on self-compacting concrete.

\section{RESEARCH SIGNIFICANCE}

Plain concrete is considered a brittle material with very low tensile strength and shear capacity. The inclusion of steel fibers into concrete mix improves ductility and toughness and can also bridge cracks and reduce crack propagation, so possibility of sudden failure can be eliminated, enhancing shear 
strength. As the interactions between concrete and steel fibers are complex, it is difficult to predict the increase in shear strength. Hence, an accurate model for predicting shear strengths of fibrous concretes is needed, enabling design engineers to use steel fibers as a commonplace building material. Work available from literature on predicting shear behaviour of SCC is scant, and the available models need to be supplemented with further experimental work to compensate for this.

\subsection{MATERIALS USED AND METHODS}

\subsubsection{CEMENT}

The cement used in the investigation was 53 Grade Ordinary Portland cement confirming to IS: 12269 [9]. The specific gravity of the cement was found to be 3.10 and the initial and final setting times were 45 and 560 min, respectively.

\subsubsection{FLY ASH}

Fly ash confirming to IS: 3812 [10] was used as mineral admixture. The fly ash used in the present study was obtained from NTPC Ramagundam and is of Class F. The specific gravity of fly ash used in the present study was 2.2 .

\subsubsection{FINE AGGREGATE (FA)}

The fine aggregate used in the present study conforms to Zone-2 according to IS: 383 [11]. It was obtained from a nearby river source. The specific gravity was 2.65 , while the bulk density of the sand was $1450 \mathrm{Kg} / \mathrm{m}^{3}$.

\subsubsection{COARSE AGGREGATE (CA)}

Crushed granite was used as a coarse aggregate. Coarse aggregates of $20 \mathrm{~mm}$ nominal size were obtained from a local crushing unit; it was well-graded aggregate according to IS: 383 [11]. The specific gravity was 2.8 , while the bulk density was $1500 \mathrm{Kg} / \mathrm{m}^{3}$.

\subsubsection{WATER}

Potable water was used in the experimental work for both mixing and curing of specimens.

\subsubsection{SILICA FUME [12]}

Silica fume is an ultrafine powder with an average particle diameter of $150 \mathrm{~nm}$ which was used in the present study. The specific gravity of silica fume is generally in the range of 2.2 to 2.3 , and its specific surface area ranges from 15,000 to $30,000 \mathrm{~m}^{2} / \mathrm{kg}$. 


\subsubsection{SUPER PLASTICIZER (SP)}

In the present study, a polycarboxylic ether-based high range water-reducing admixture confirming to ASTM C494 [13] obtained from Chyrso Chemicals, India, commonly called a super plasticizer was used. The major advantage of using a super plasticizer is improving the flowing ability of high-performance concretes at lower water-cement ratios.

\subsubsection{STEEL FIBER [14]}

Crimped steel fibers (from Apex Encon Projects Pvt, Ltd., New Delhi, India) with a nominal fiber diameter of $0.5 \mathrm{~mm}$ and a cut length of $30 \mathrm{~mm}$ with an aspect ratio of 60 were used. The tensile strength and modulus of elasticity of this fiber is $850 \mathrm{MPa}$ and $2.1 \times 10^{5} \mathrm{MPa}$, respectively.

\subsubsection{TENSION REINFORCEMENT}

TMT bars 12 and $16 \mathrm{~mm}$ diameter of Fe 500 grade confirming to IS: 1786 [15] whose yield strength was $500 \mathrm{~N} / \mathrm{mm}^{2}$ and length $1160 \mathrm{~mm}$ were used as tension reinforcements, and $6 \mathrm{~mm} \emptyset$ mild steel bars whose yield strength was $290 \mathrm{~N} / \mathrm{mm}^{2}$ were used as top compression reinforcements. Two-legged $6 \mathrm{~mm} \emptyset$ mild steel bars whose yield strength was $290 \mathrm{~N} / \mathrm{mm}^{2}$ and two-legged $8 \mathrm{~mm} \varnothing$ TMT bars whose yield strength was $290 \mathrm{~N} / \mathrm{mm}^{2}$ were used as stirrups (shear reinforcement).

\subsection{EXPERIMENTAL PROGRAMME}

In the present study, a total of 16 shear-deficient beams were designed and cast for two grades of SCC, M30 and M70. Two stirrup diameters of 6 and $8 \mathrm{~mm}$ were used to study the effects of stirrup diameter and two stirrup spacing markers were considered $(180 \mathrm{~mm}$ and $360 \mathrm{~mm})$ to study the effects of stirrup spacing on shear behaviour. The dimensions of the beam were fixed as $100 \times 200 \times 1200 \mathrm{~mm}$ with a clear span of $1100 \mathrm{~mm}$. All beams were tested under three-point loading.

For compressive strength, standard cast iron cube moulds measuring $150 \mathrm{~mm} \times 150 \mathrm{~mm} \times 150 \mathrm{~mm}$ were used. For split tensile strength, standard cast iron cylinder moulds measuring $150 \mathrm{~mm} \varphi \times 300 \mathrm{~mm}$ were used. For flexural strength, a $100 \mathrm{~mm} \times 100 \mathrm{~mm} \times 500 \mathrm{~mm}$ standard prism mould was used. For all the above tests, the average of three specimens were considered. In the present study, the proportion of steel fibers is taken as $0.5 \%$ to the volume of concrete [16].

Table 1 shows the details of the beams with different spacing of stirrups, and percentage of steel fibers per volume of concrete. 
Table 1: Details of beams for $6 \mathrm{~mm}$ and $8 \mathrm{~mm} \varnothing$ stirrups for $\mathrm{a} / \mathrm{d}=2$

\begin{tabular}{|c|c|c|}
\hline $\begin{array}{c}\text { Beam } \\
\text { Designation }\end{array}$ & $\begin{array}{c}\text { Stirrups } \\
\text { Spacing (mm) }\end{array}$ & $\begin{array}{c}\text { Fiber } \\
\text { content } \\
\mathrm{Kg} / \mathrm{m} 3\end{array}$ \\
\hline SCC30-180 & 180 & 0 \\
\hline SCC30-360 & 360 & 0 \\
\hline SFRSCC30-180 & 180 & 38 \\
\hline SFRSCC30-360 & 360 & 38 \\
\hline SCC70-180 & 180 & 0 \\
\hline SCC70-360 & 360 & 38 \\
\hline SFRSCC70-180 & 180 & 38 \\
\hline
\end{tabular}

The above beams were cast using $6 \mathrm{~mm}$ diameter stirrups; similarly, the remaining 8 beams were cast using $8 \mathrm{~mm}$ diameter stirrups.

\subsection{REINFORCEMENT DETAILS}

The dimensions and typical reinforcement details for both grades of SCC and for shear span-to-depth ratios $(\mathrm{a} / \mathrm{d}=2)$ are shown in Figures 1 and 2 . The stirrup spacing varied in the shear span. For each beam, two stirrup spacing locations were considered. M30 grade SCC beams consisted of 2-12mm Ø TMT bars as longitudinal reinforcement and $2-6 \mathrm{~mm} \varnothing$ mild steel bars as compression reinforcement. Similarly, M70 grade SCC beams consisted of 2-16mm and 1-12mm Ø bars as longitudinal reinforcement, 2-6mm $\varnothing$ mild steel bars as compression reinforcement, and two-legged $6 \mathrm{~mm}$ and $8 \mathrm{~mm} \varnothing$ bars were used as stirrups.

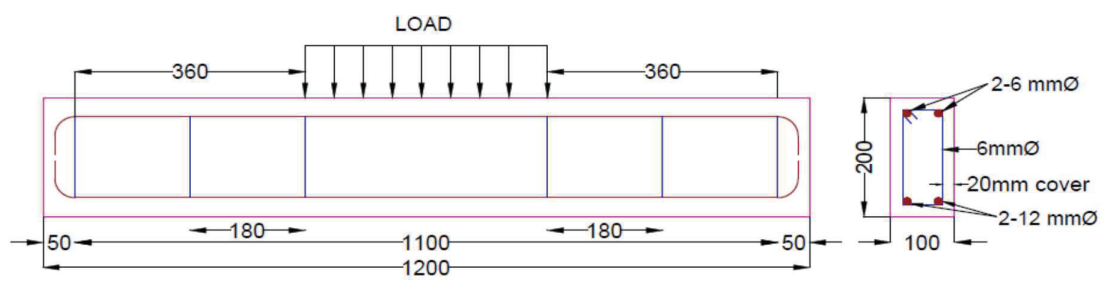




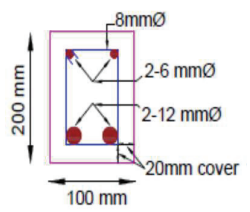

Figure 1(a)

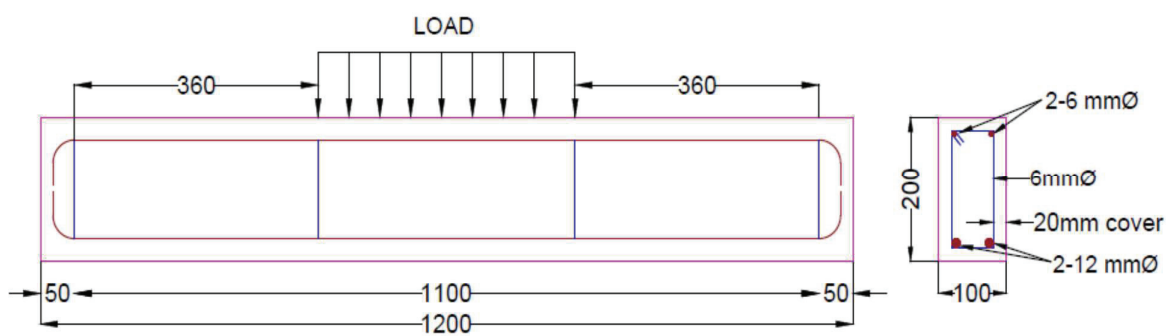

Figure: 1(b)

Figure 1: Details of reinforcement for M30 mix with $\mathrm{a} / \mathrm{d}=2$
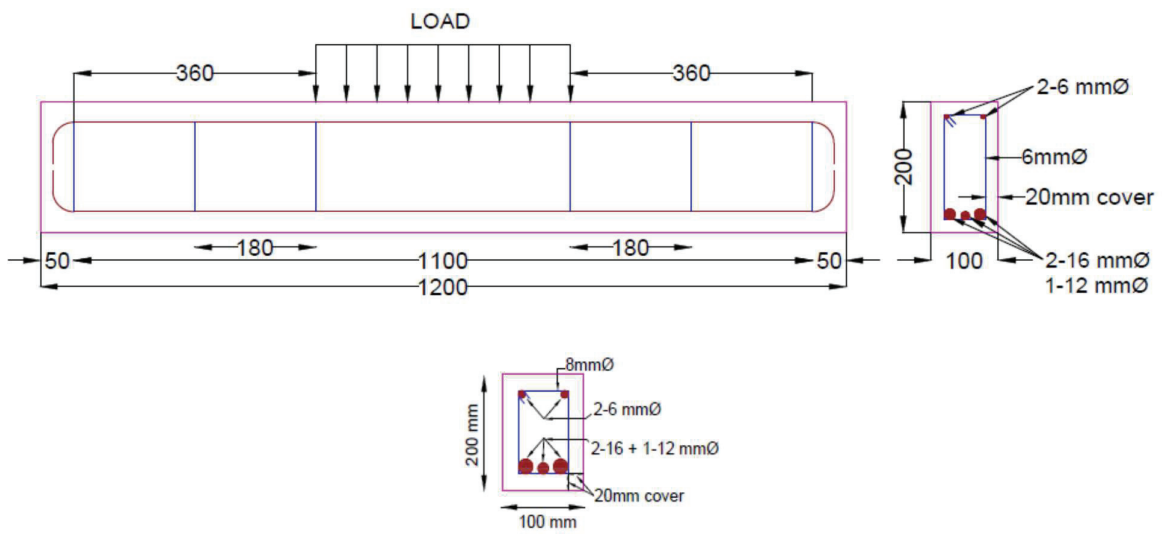

Figure 2(a) 

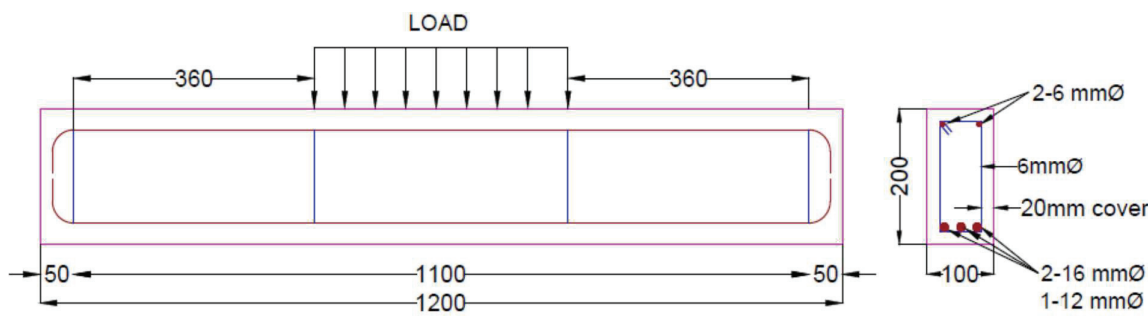

Figure: 2(b)

Figure 2: Details of reinforcement for M70 Mix with $\mathrm{a} / \mathrm{d}=2$

\subsection{PROPORTIONS}

Self-compacting concrete (SCC) mix was designed using the rational mix design method [17]. The details of the mix proportions are presented in Table 2 . Trial mixes were carried out by varying super plasticizer dosages and binder content, and the fresh properties were evaluated as per EFNARC specifications [18] via slump flow, $\mathrm{T}_{50}$, L-box, V-funnel, $\mathrm{T}_{5}$, and J-ring tests.

Table 2: Mix proportions of M30 and M70 grade SCC

\begin{tabular}{|l|c|c|c|c|c|c|c|c|}
\hline Mix & $\begin{array}{c}\text { Cement } \\
\left(\mathrm{kg} / \mathrm{m}^{3}\right)\end{array}$ & $\begin{array}{c}\text { Fly ash } \\
\left(\mathrm{kg} / \mathrm{m}^{3}\right)\end{array}$ & $\begin{array}{c}\text { Silica } \\
\text { fume } \\
\left(\mathrm{kg} / \mathrm{m}^{3}\right)\end{array}$ & $\begin{array}{c}\mathrm{CA} \\
\left(\mathrm{kg} / \mathrm{m}^{3}\right)\end{array}$ & $\begin{array}{c}\text { FA } \\
\left(\mathrm{kg} / \mathrm{m}^{3}\right)\end{array}$ & $\begin{array}{c}\text { Water } \\
\left(\mathrm{kg} / \mathrm{m}^{3}\right)\end{array}$ & W/b & $\begin{array}{c}\text { SP } \\
\left(\mathrm{kg} / \mathrm{m}^{3}\right)\end{array}$ \\
\hline M30 & 350 & 324 & 0 & 746 & 945 & 203 & 0.30 & 5.73 \\
\hline M70 & 600 & 226 & 48 & 780 & 874 & 247 & 0.28 & 6.03 \\
\hline
\end{tabular}

\subsection{FRESH PROPERTIES OF M30 \& M70 GRADE SCC WITH AND WITHOUT STEEL FIBERS}

The details of the fresh properties of both M30 and M70 grade SCC with and without steel fibers are shown in Table 3. 
Table 3: Fresh properties of M30 and M70 grade SCC without and with fiber

\begin{tabular}{|c|c|c|c|c|c|c|}
\hline Grade of Concrete & \multicolumn{2}{|c|}{ M30 } & \multicolumn{2}{c|}{ M70 } & \multicolumn{2}{c|}{ EFNARC 2005 } \\
\hline Dosage of Fibers & $0 \%$ & $0.5 \%$ & $0 \%$ & $0.5 \%$ & Min. & Max. \\
\hline Slump Test (mm) & 750 & 620 & 720 & 680 & 550 & 800 \\
\hline $\mathrm{T}_{50}$ Slump Flow (sec) & 3 & 5 & 2.5 & 4 & 2 & 5 \\
\hline V-Funnel (sec) & 6 & 6.5 & 10.5 & 11.8 & 6 & 12 \\
\hline V-Funnel @ $\mathrm{T}_{5}$ min (sec) & 7.5 & 8.3 & 12 & 14 & 6 & 15 \\
\hline J-ring (sec) & 3 & 8 & 3 & 7 & 0 & 10 \\
\hline
\end{tabular}

It can be seen from Table 3 that the addition of steel fibers has reduced flow properties, though it still satisfies EFNARC (European Federation of National Associations Representing for Concrete) specifications. Figure 3 shows the various tests conducted on the workability of SCC.

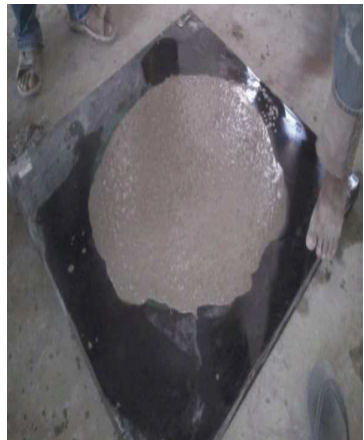

a) Slump flow

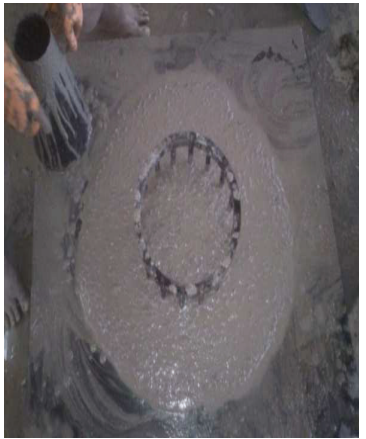

b) J-ring

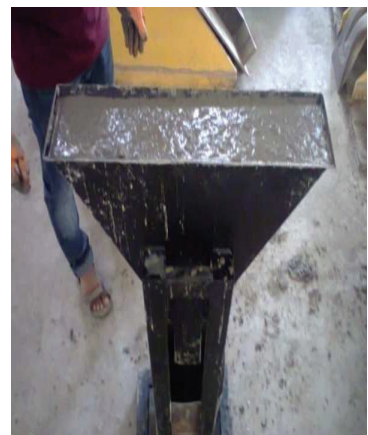

c) V-funnel

Figure 3: Some tests on the workability of SCC

\subsection{HARDENED PROPERTIES OF SELF-COMPACTING CONCRETE WITH AND WITHOUT STEEL FIBERS}

Details of the hardened properties of the M30 and M70 grades of SCC with and without steel fibers at the age of 28 days are shown in Table 4. All the tests were done as per IS: 516 [19] specifications. 
Table 4: Hardened properties of M30 and M70 grades of SCC at 28 days

\begin{tabular}{|c|c|c|c|c|c|c|}
\hline & \multicolumn{3}{|c|}{ M30 } & \multicolumn{3}{c|}{ M70 } \\
\hline $\begin{array}{c}\text { Dosage of } \\
\text { Steel Fibers }\end{array}$ & $\begin{array}{c}\text { Compressive } \\
\text { Strength (MPa) }\end{array}$ & $\begin{array}{c}\text { Split Tensile } \\
\text { Strength } \\
(\mathrm{MPa})\end{array}$ & $\begin{array}{c}\text { Flexural } \\
\text { Strength } \\
(\mathrm{MPa})\end{array}$ & $\begin{array}{c}\text { Compressive } \\
\text { Strength (MPa) }\end{array}$ & $\begin{array}{c}\text { Split Tensile } \\
\text { Strength } \\
(\mathrm{MPa})\end{array}$ & $\begin{array}{c}\text { Flexural } \\
\text { Strength } \\
(\mathrm{MPa})\end{array}$ \\
\hline $0 \%$ & 39.67 & 4.17 & 3.98 & 78.25 & 5.04 & 5.34 \\
\hline $0.5 \%$ & 48.76 & 4.34 & 4.87 & 86.66 & 5.85 & 6.41 \\
\hline
\end{tabular}

\section{RESULTS AND DISCUSSIONS}

At the end of the required curing period the beams were tested for three-point loading with the Tinius Olsen Testing Machine (TOTM) under $2000 \mathrm{kN}$ capacity. The linear variable differential transformers (LVDT) were used to measure beam displacement at mid-span. From the recorded data, graphs of shear load vs. deflection were plotted, and initial crack strength and ultimate shear strength were calculated. The toughness and stiffness were evaluated for M30 and M70 grade SCC with and without steel fibers. Tables 5 and 6 show the ultimate load and shear strength of fibrous and non-fibrous SCC beams for different stirrup diameters $(6 \mathrm{~mm}$ and $8 \mathrm{~mm})$.

Table 5: Initial crack strength, Ultimate shear strength, Toughness, and Stiffness for $6 \mathrm{~mm}$ Q stirrups

\begin{tabular}{|c|c|c|c|c|c|c|}
\hline Designation & $\begin{array}{c}\text { Shear Strength at } \\
\text { First Crack }\left(\tau_{u c}\right) \\
(\mathrm{MPa})\end{array}$ & $\begin{array}{c}\text { Ultimate } \\
\text { Load }\left(\mathrm{v}_{\mathrm{u}}\right) \\
\mathrm{kN}\end{array}$ & $\begin{array}{c}\text { Ultimate Shear } \\
\text { Strength }\left(\tau_{u c}\right) \\
(\mathrm{MPa})\end{array}$ & $\begin{array}{c}\text { Deflection } \\
(\mathrm{mm})\end{array}$ & $\begin{array}{c}\text { Shear } \\
\text { Toughness } \\
(\mathrm{kN}-\mathrm{mm})\end{array}$ & $\begin{array}{c}\text { Stiffness } \\
(\mathrm{kN} / \mathrm{mm})\end{array}$ \\
\hline SCC30-180 & 1.98 & 95.67 & 2.66 & 4.18 & 234.27 & 18.23 \\
\hline SCC30-360 & 1.76 & 86.77 & 2.41 & 4.12 & 182.2 & 17.68 \\
\hline SFRSCC30-180 & 2.29 & 117.92 & 3.28 & 6.90 & 464.1 & 22.52 \\
\hline SFRSCC30-360 & 2.16 & 102.35 & 2.84 & 5.21 & 328 & 20.17 \\
\hline SCC70-180 & 2.16 & 115.7 & 3.21 & 4.92 & 365.7 & 29.17 \\
\hline SCC70-360 & 2.10 & 93.67 & 2.60 & 3.54 & 212.2 & 28.07 \\
\hline SFRSCC70-180 & 3.52 & 159.75 & 4.44 & 5.90 & 525.03 & 36.47 \\
\hline SFRSCC70-360 & 2.41 & 138.83 & 3.86 & 5.40 & 483.46 & 31.47 \\
\hline
\end{tabular}


Table 6: Initial crack strength, Ultimate shear strength, Toughness, and Stiffness for $8 \mathrm{~mm} \otimes$ stirrups

\begin{tabular}{|c|c|c|c|c|c|c|}
\hline Designation & $\begin{array}{c}\text { Shear Strength at } \\
\text { First Crack }\left(\tau_{u c}\right) \\
(\mathrm{MPa})\end{array}$ & $\begin{array}{c}\text { Ultimate } \\
\text { Load }\left(\mathrm{v}_{\mathrm{u}}\right) \\
\mathrm{kN}\end{array}$ & $\begin{array}{c}\text { Ultimate Shear } \\
\text { Strength }\left(\tau_{u c}\right) \\
(\mathrm{MPa})\end{array}$ & $\begin{array}{c}\text { Deflection } \\
(\mathrm{mm})\end{array}$ & $\begin{array}{c}\text { Shear } \\
\text { Toughness }(\mathrm{kN}- \\
\mathrm{mm})\end{array}$ & $\begin{array}{c}\text { Stiffness } \\
(\mathrm{kN} / \mathrm{mm})\end{array}$ \\
\hline SCC30-180 & 2.17 & 113.62 & 3.16 & 3.90 & 252 & 29.58 \\
\hline SCC30-360 & 1.49 & 100.65 & 2.80 & 3.64 & 144 & 28.58 \\
\hline SFRSCC30-180 & 2.42 & 127.04 & 3.53 & 5.24 & 436 & 34.41 \\
\hline SFRSCC30-360 & 1.93 & 122.57 & 3.40 & 4.52 & 318 & 30.52 \\
\hline SCC70-180 & 2.80 & 174.59 & 4.85 & 9.82 & 1471 & 37.37 \\
\hline SCC70-360 & 2.39 & 143.15 & 3.98 & 5.20 & 513 & 33.53 \\
\hline SFRSCC70-180 & 3.17 & 199.06 & 5.53 & 5.32 & 1588 & 51.70 \\
\hline SFRSCC70-360 & 2.67 & 158.80 & 4.41 & 5.63 & 586 & 38.01 \\
\hline
\end{tabular}

\subsection{EFFECTS OF STIRRUP DIAMETER ON SHEAR STRENGTH OF SFRSCC BEAMS}

The effects of stirrup diameter size on shear strength $\left(\tau_{u c}=\frac{V_{u}}{b d}\right)$ are shown in Figs. 4 and 5 . It can be observed from Tables 5 and 6 that as the area of shear reinforcement increases, ultimate load and ultimate shear strengths also increases.

1. For constant stirrup spacing, the load-carrying capacity of beam SCC30-180 with an $8 \mathrm{~mm}$ diameter stirrup is $18.8 \%$ higher compared to that of a similar beam with a $6 \mathrm{~mm}$ diameter.

2. Similarly, for the beams with the higher grade of concrete for constant spacing of the stirrup, i.e. SCC70-180 with an 8mm diameter stirrup, the load-carrying capacity is higher than that of the beam with a $6 \mathrm{~mm}$ diameter.

3. Similarly, the addition of fibers for constant spacing of a stirrup has increased shear strength by $8 \%$ for M30 grade concrete with the $8 \mathrm{~mm}$ stirrup diameter, compared to the $6 \mathrm{~mm}$ diameter, whereas for the higher grade of concrete, M70, shear strength increased by $24.5 \%$.

4. For beam SFCC30-180 with the $6 \mathrm{~mm}$ diameter, shear strength increased slightly, by $3.5 \%$, compared to the beam with no fibers and with the $8 \mathrm{~mm}$ diameter stirrup. Similarly, for the beam with the higher grade of concrete, SFSCC70-180 with the $6 \mathrm{~mm}$ diameter, shear strength decreased slightly, by $8.4 \%$, compared to the beam with no fibers and with the $8 \mathrm{~mm}$ diameter stirrup.

5. The combination of fibers and stirrups has shown a positive hybrid effect on the shear strength of self-compacting concrete.

6. Beam toughness also increased with the addition of stirrups and steel fibers. 


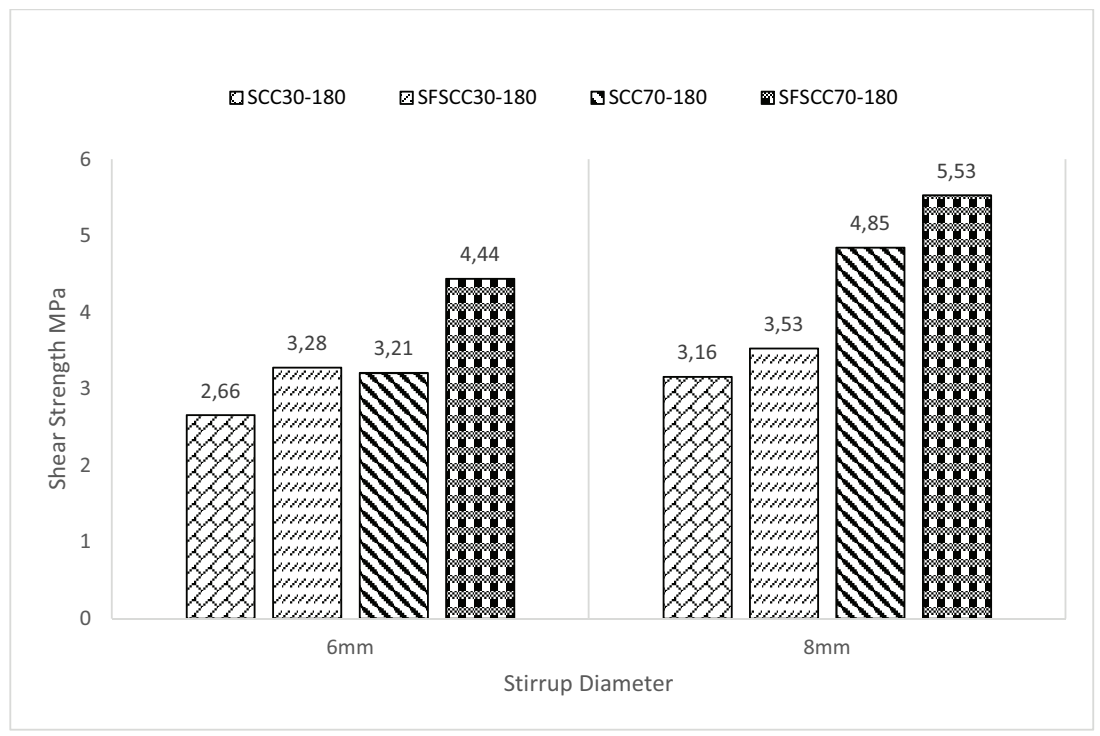

Figure 4: Shear strength vs. stirrup diameter for $180 \mathrm{~mm}$ spacing

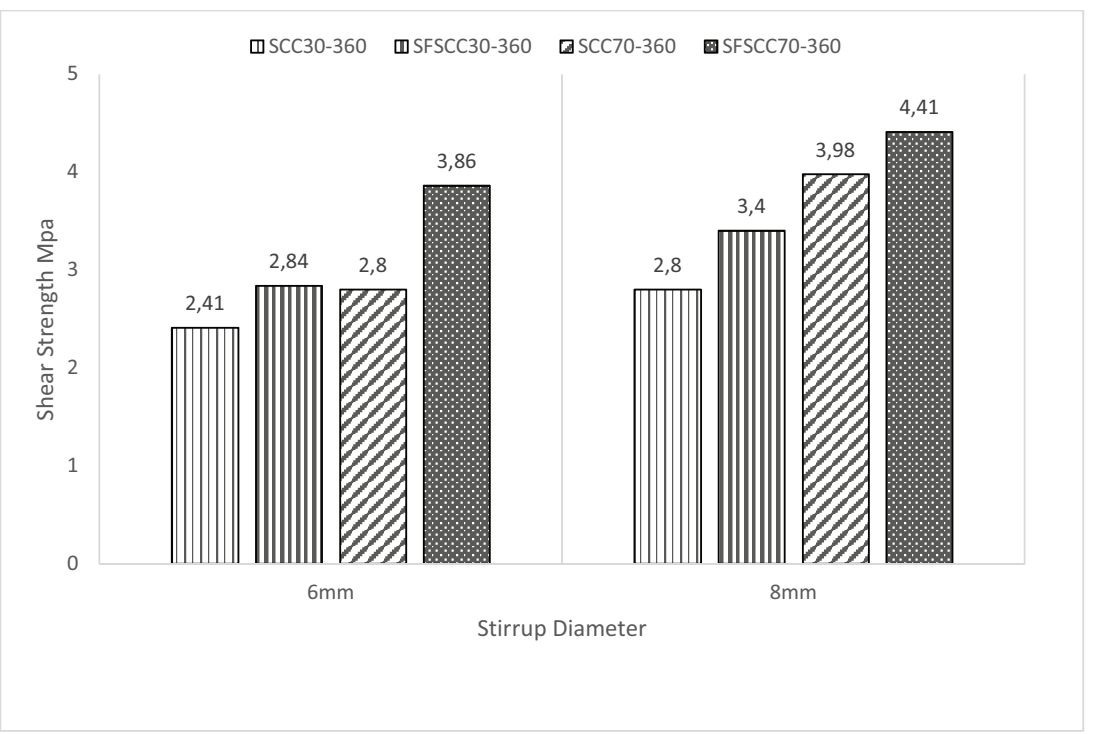

Figure 5: Shear strength vs. stirrup diameter for $360 \mathrm{~mm}$ spacing 


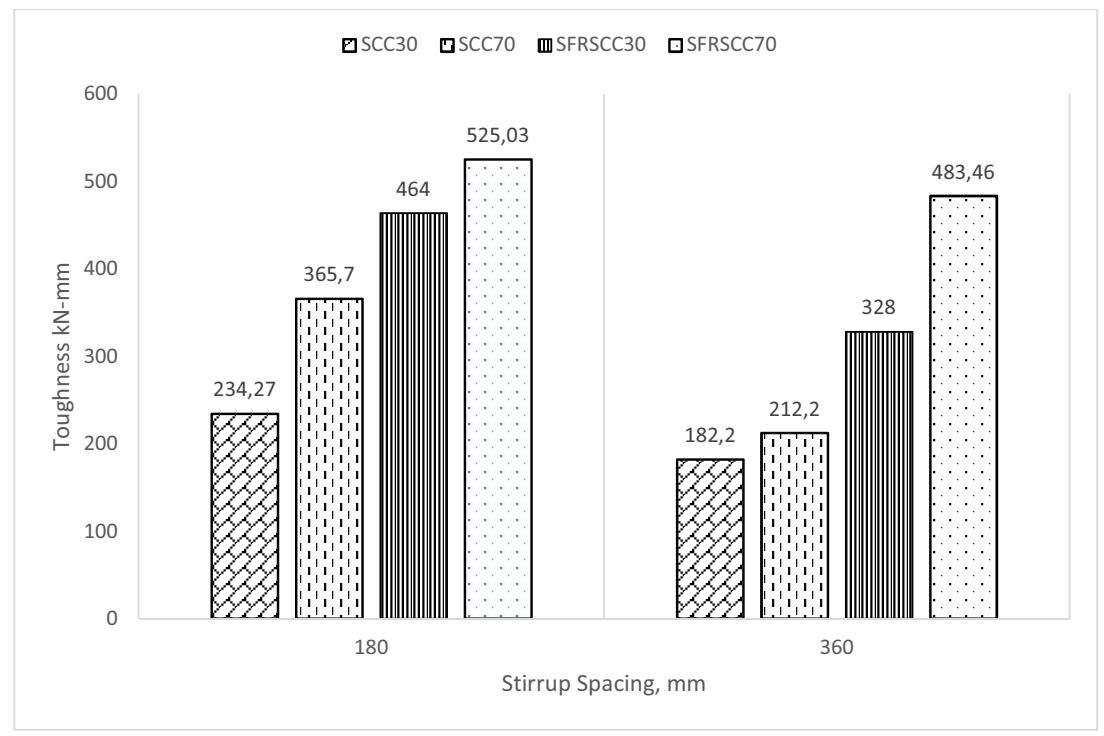

Figure 6: Toughness vs. stirrup spacing for $6 \mathrm{~mm} \otimes$ stirrup

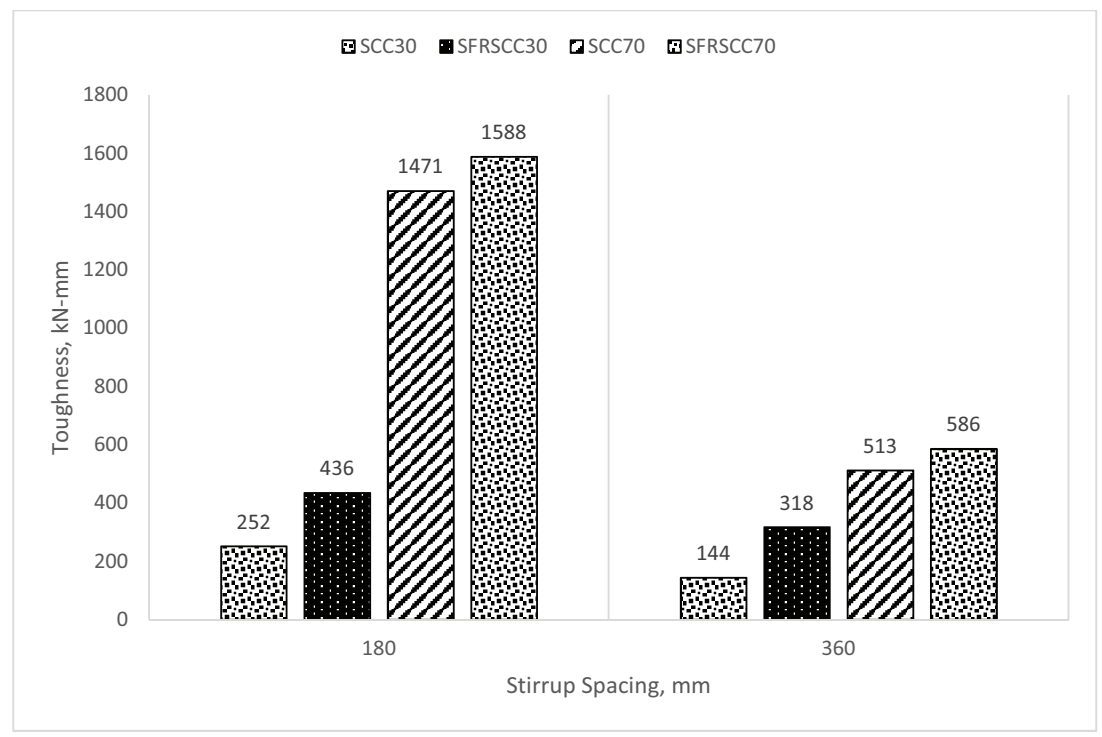

Figure 7: Toughness vs. stirrup spacing for $8 \mathrm{~mm}$ Q stirrup 


\subsection{LOAD-DISPLACEMENT CURVES}

From the recorded data load displacement curves were plotted, and shear toughness and energy absorption, i.e. stiffness at the peak shear load, were calculated. Figures $8(\mathrm{a})$ and 8 (b) show a comparison of load deflection curves for SCC and SFRSCC for stirrup diameters of $6 \mathrm{~mm}$ and $8 \mathrm{~mm}$ for M30 grade concrete. It can be observed that the SCC30-180 with the $6 \mathrm{~mm}$ diameter stirrup beam shows lower loadcarrying capacity than the SCC30-180 with the 8mm diameter stirrup. With an increase in the area of shear reinforcement, the shear strength of the beam increased by $18.8 \%$ and the addition of steel fibers increased the shear strength by $8 \%$. Similar behaviour was observed as the spacing of stirrups increased from $180 \mathrm{~mm}$ to $360 \mathrm{~mm}$.

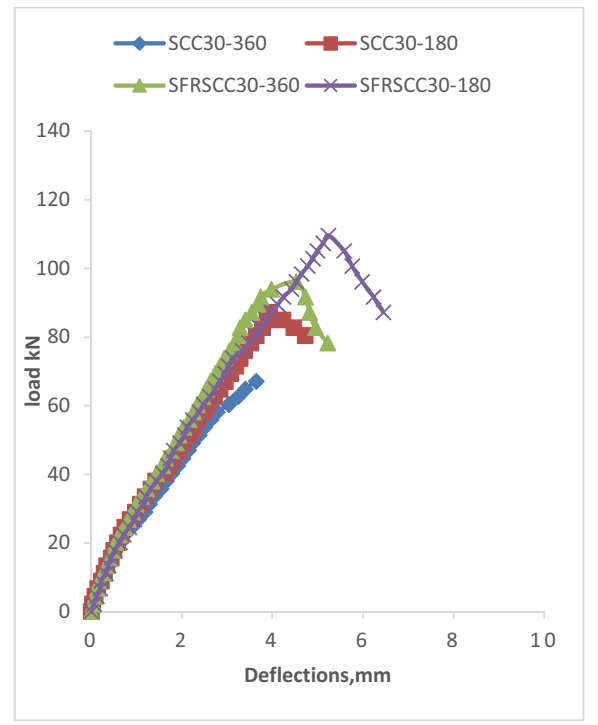

Figure 8(a): Load vs. deflections for SCC 30; 8mm a stirrup

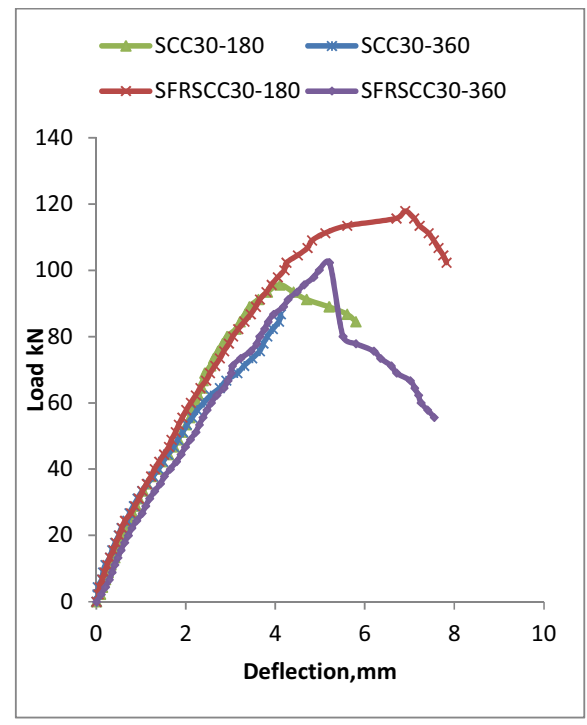

Figure 8(b): Load vs. deflections for SCC 30; 6mm a stirrup

Figures 9(a) and 9(b) show a comparison of load deflection curves for SCC and SFRSCC for stirrup diameters $6 \mathrm{~mm}$ and $8 \mathrm{~mm}$ for M70 grade concrete. It was observed that the SCC 70-180 beam with a $6 \mathrm{~mm}$ diameter stirrup showed a lower load-carrying capacity compared to SCC $70-180$ with an 8mm 
diameter stirrup. As the area of shear reinforcement increased, the ultimate load and ultimate shear strength increased by $68.53 \%$. A similar trend was observed as spacing of stirrups increased from 180 $\mathrm{mm}$ to $360 \mathrm{~mm}$ - shear strength increased by $53.07 \%$.

The addition of steel fibers increased the load-carrying capacity and shear strength of the SCC70 beam by modifying the failure mode from brittle to ductile. From Tables 5 and 6 it can be observed that the shear strength of the SFRSCC70-180 beam with the $6 \mathrm{~mm}$ diameter stirrup is $24.5 \%$ lower than that of the SFRSCC70-180 beam with the $8 \mathrm{~mm}$ diameter stirrup.

From the above discussions it can be concluded that an increase in the area of shear reinforcement can greatly improve the shear strength of self-compacting concrete. For identical diameter sizes of the stirrup, the addition of fibers increased shear strength and the failure mode changed from brittle shear failure to ductile failure. The beam without steel fibers failed early after the first diagonal crack occurred.

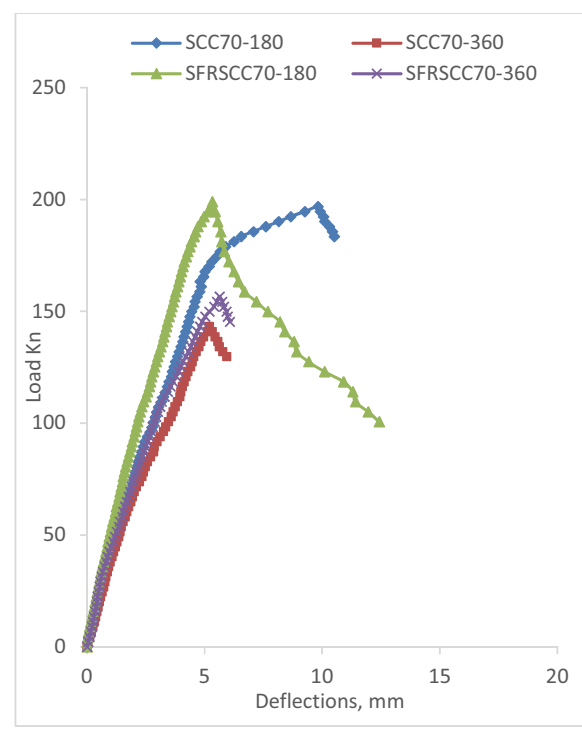

Figure 9(a): Load vs. deflections for SCC 70; 8mm Q stirrup

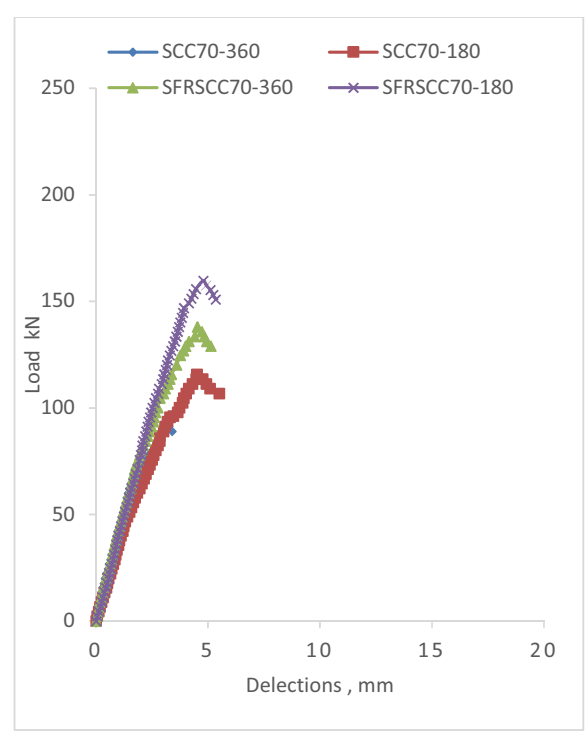

Figure 9(b): Load vs. deflections for SCC 70; 6mm Q stirrup 


\section{COMPARISON OF TEST RESULTS WITH MODELS FROM LITERATURE}

The experimental results obtained from the ultimate shear strength tests of non-fibrous SCC and fibrous SCC are compared with shear strength models available for vibrated concrete below.

\subsection{NON-FIBROUS SCC}

(a) Russo et al. [20]

After a detailed investigation of 116 high strength concrete (HSC) beams with stirrups as shear reinforcement, Russo et al. [20] proposed an equation to calculate average shear strength $\left(\mathrm{V}_{\mathrm{uc}}\right)$. The parameters varied in the investigation were compressive strength $\left(\mathrm{f}_{\mathrm{c}}\right)$, shear span-to-depth ratio $(\mathrm{a} / \mathrm{d})$, and stirrup ratio. For beams without shear reinforcement the shear stress is due to arch and beam action.

$$
\begin{array}{cr}
V_{u c}=V_{\mathrm{a}}+V_{\mathrm{b}} & \operatorname{Eq(1)} \\
V_{\mathrm{uc}}=\xi\left[0.97 \rho_{\mathrm{s}}^{0.46} \mathbf{f}_{\mathrm{c}}^{\frac{11}{2}}+0.2 \rho_{\mathrm{s}}^{0.91} \mathbf{f}_{\mathrm{c}}^{\prime 0.38} \mathbf{f}_{\mathrm{y} 1}^{0.96}(\mathrm{a} / \mathrm{d})^{-2.33}\right] & \mathbf{E q ( 2 )} \\
\text { Where, } \xi=1 / \sqrt{1+\mathrm{d} /\left(25 d_{\mathrm{a}}\right)} & \mathbf{E q ( 3 )} \\
\rho_{\mathrm{s}}=\mathbf{A}_{\mathrm{s}} /(\mathrm{bd}) & \mathbf{E q ( 4 )}
\end{array}
$$

Where $v_{a} a n d v_{b}$ are the shear stresses due to arch and beam actions, respectively, $\xi$ is the factor taking into account size effects, $d$ is the effective depth of the beam, $d_{a}$ is the maximum size of the coarse aggregate, $f^{\prime}{ }_{c}$ is the compressive strength of the circular cylinder, $\rho_{\mathrm{s}}$ is the longitudinal reinforcement ratio, $f_{y 1}$ is the yielding strength of the longitudinal reinforcement, and $\mathrm{a} / \mathrm{d}$ is the shear span-to-depth ratio. A third term must be added to equation (1) when stirrups are present.

$$
\begin{array}{cc}
\mathrm{V}_{\mathrm{u}}=\mathrm{V}_{\mathrm{uc}}+\mathrm{V}_{\mathrm{s}} & \operatorname{Eq(5)} \\
\mathrm{V}_{\mathrm{s}}=1.75 I_{b} \rho_{s t} f_{y s t} & \operatorname{Eq(6)} \\
\text { Where, } I_{b}=\frac{0.97 \rho_{s}^{0.46} f_{c}^{\prime 1 / 2}}{0.97 \rho_{s}^{0.46} f_{c}^{\prime 1 / 2}+0.2 \rho_{s}^{0.91} f_{c}^{\prime 0.38} f_{y 1}^{0.96}(a / d)^{-2.33}} & \operatorname{Eq(7)} \\
\rho_{s}=\mathbf{A}_{\mathrm{s}} /(\mathrm{bd}) & \operatorname{Eq(8)}
\end{array}
$$

Where $V_{\mathrm{s}}$ is the shear stress due to the stirrups, $I_{b}$ is the index of beam action, $f_{\mathrm{yst}}$ is the yielding strength of the stirrup, and $\rho_{s t}$ is the stirrup ratio evaluated with reference to spacing s.

(b) Chinese Code for Design of Concrete Structures, GB50010-2002 [24] 
After a detailed investigation of beams with different grades of concrete and stirrups ratios, Chinese code [23] proposed an equation for vibrated concrete to calculate the shear strength:

$$
\begin{gathered}
V_{U}=\frac{1.75}{1+\lambda} f_{t} b d+f_{y s t} \frac{A_{s t}}{s} d, \\
v_{u}=\frac{V_{u}}{b d}
\end{gathered}
$$

Here, $V_{u}$ is the shear load of the RC member, $f_{t}$ is the tensile strength of the prism, $\lambda$ is the shear spanto-depth ratio, $v_{u}$ is the shear strength of the RC member, and $\mathrm{s}$ is spacing(c) ACI code 318-14 [25]

After a detailed investigation of beams with different grades of concrete, different yield strengths, and stirrups ratio, ACI committee 318 has given an equation to calculate shear strength for vibrated concrete

$$
v_{u}=\frac{1}{7}\left[\sqrt{f^{\prime}}{ }_{c}+120 \rho_{s}\left(\frac{d}{a}\right)\right]+\rho_{s t} f_{y s t}
$$

where $\boldsymbol{v}_{\boldsymbol{u}}$ is the shear strength, $f^{\prime}{ }_{c}$ is the average compressive strength of concrete, $\rho_{\text {st }}$ is the longitudinal reinforcement ratio, $f_{y s t}$ is the yielding strength of the longitudinal reinforcement, and a/d is the shear span-to-depth ratio.

\section{(d) EURO Code-2 [26]}

A design equation specified by Eurocode 2 (2004) for shear resistance $\left(V_{R d c}\right)$ of the members without shear reinforcement is as follows:

$$
\mathbf{V}_{\mathrm{Rdc}}=\mathbf{C}_{\mathrm{Rd}, \mathrm{c}} * \mathbf{k}^{*}\left[100 * \rho_{s t} * \boldsymbol{f}_{c k}\right]^{1 / 3} * \mathbf{b}_{\mathrm{w}} * \mathbf{d}
$$

where, $\mathrm{C}_{\mathrm{Rd}, \mathrm{c}}=$ Co-efficient derived from tests $=\frac{0.18}{\gamma_{\mathrm{c}}}=0.12$

$$
\begin{aligned}
& \mathrm{k}=\text { Size factor }=1+\sqrt{\frac{200}{d}} \\
& \mathrm{f}_{\mathrm{ck}}=\text { Characteristic concrete compressive strength at } 28 \text { days } \\
& \mathrm{b}_{\mathrm{w}}=\text { Smallest web width } \\
& \mathrm{d}=\text { Effective depth of cross-section } \\
& \rho_{\mathrm{st}}=\frac{A_{s t}}{b_{w} d} \text { is the longitudinal reinforcement ratio }
\end{aligned}
$$

For reinforced concrete members with vertical shear reinforcement, shear resistance, 
$\mathrm{V}_{\mathrm{Rd}}$, s, should be taken to lower, either

$$
\begin{gathered}
\mathrm{V}_{\mathrm{Rd}, \mathrm{s}}=\frac{A_{s w}}{s} \boldsymbol{z} \boldsymbol{f}_{y} \cot \theta \\
\text { Or } \\
\mathrm{V}_{\mathrm{Rd}, \mathrm{s} \max }=\frac{\alpha_{c} b_{w} z v f_{c d}}{\cot \theta+\tan \theta}
\end{gathered}
$$

where $V_{R d, s}$ is the design value of the shear force which can be sustained by the yielding shear reinforcement; $\mathrm{V}_{\mathrm{Rd} \text {,max }}$ is the design value of the maximum shear force which can be sustained by the member (limited by crushing of the compression struts), $\mathrm{A}_{\mathrm{sw}}$ is the cross-sectional area of the shear reinforcement; $s$ is the spacing of the stirrups; $Z$ is the lever arm (which may be considered as $Z=0.9 \mathrm{~d}$ ), $\mathbf{f}_{\mathbf{y}}$ is the yield strength of the shear reinforcement, $\theta$ is the angle of the inclined struts, bw is the width of the web, $\mathbf{f}_{\mathbf{c d}}$ is the design of the compressive cylinder strength of concrete at 28 days, and $\boldsymbol{\alpha}_{\boldsymbol{c}}$ is a coefficient which takes into account the effect of normal stresses on shear strength. The recommended value of $\boldsymbol{\alpha}_{\boldsymbol{c}}$ is 1 for non-prestressed structures and 1.25 for prestressed structures.

Also, $v$ is a coefficient which takes into account the increase in fragility and the reduction of shear transfer by aggregate interlock with an increase of the compressive concrete strength. It may be assumed to be 0.6 for $\mathrm{f}_{\mathrm{ck}} \leq 60 \mathrm{MPa}$, and $0.92-\mathrm{f}_{\mathrm{ck}} / 200>0.5$ for high strength concrete beams.

\subsection{Fibrous SCC:}

\section{(a) Narayanan and Darwish [1]}

Using steel fibers as shear reinforcement, Narayanan and Darwish [1] proposed a formula for shear stress due to fibers $\left(v_{f}\right)$. The parameters which varied in their investigation were volume fraction $(\mathrm{F})$ of the fibers, fiber aspect ratio ( $1 / \mathrm{d})$, concrete compressive strength $\left(f_{\mathrm{cu}}\right)$, amount of longitudinal reinforcement $\left(\boldsymbol{\rho}_{s t}\right)$, and the shear span/effective depth ratio a/d.

$$
v_{f}=0.41 * \tau * \boldsymbol{F}
$$

Here, $F=\left(\frac{l_{f}}{d_{f}}\right) V_{f} k_{f}$, where $V_{f}$ is shear stress due to steel fibers, $\tau$ is the average fibre matrix interfacial bond stress ( $\tau=4.15 \mathrm{MPa}$ ), $F$ is the fibre factor, $\left(\frac{l_{f}}{d_{f}}\right)$ is the fibre aspect ratio, and $k_{f}$ is the bond factor accounting for differing bond characteristics of the fibres. It is assigned a relative value of 0.5 for round fibers, 0.75 for crimped fibers, and 1.0 for indented fibers. In the present case, the value of $k_{f}$ is taken as $=0.75$ as crimped fibers were used in the study. 


\section{(b) Ta'an and Feel [21]}

A model was proposed to predict the ultimate shear strength of fiber-reinforced concrete rectangular beams by Ta'an and Feel [21]. A total of 89 beams were tested; all failed in shear. The factors influencing the shear strength of fiber concrete beams were found to be the shear span-to-depth ratio, main reinforcement volume, dimensions, and type.

$$
v_{f}=\left(\frac{\mathbf{8 . 5}}{9}\right) * \boldsymbol{k} * V_{f} *\left(\frac{l_{f}}{d_{f}}\right)
$$

Here, $\mathrm{k}$ is a factor reflecting the fiber shape. For crimped fibers, $\mathrm{k}=0.75, V_{f}$ is the fibre volume fraction and $\left(\frac{l_{f}}{d_{f}}\right)$ is the fibre aspect ratio.

(c) Swamy et al. [22]

To assess the effectiveness of steel fibers used as shear reinforcement in lightweight concrete beams, Swamy et al. [22] have proposed a truss model to predict ultimate shear strength,

$$
v_{f}=0.37 * \tau * V_{f} *\left(\frac{l_{f}}{d_{f}}\right)
$$

where $\tau$ is equal to $4.15 \mathrm{MPa}$, as suggested by Narayanan and Darwish [1], $V_{f}$ is the fibre volume fraction, and $\left(\frac{l_{f}}{d_{f}}\right)$ is the fibre aspect ratio.

\section{(d) Lim and Oh [23]}

An analytical model to predict shear strength of fiber-reinforced concrete was proposed by Lim and Oh [23]. A total of nine beams were cast by varying the volume fraction of steel fibers and the ratio of stirrups to the required shear reinforcement.

$$
v_{f}=0.5 * \tau * V_{f} *\left(\frac{l_{f}}{d_{f}}\right) * \cot \alpha
$$

Here, ' $\alpha$ ' is the inclination between the longitudinal reinforcement and the shear crack, and is equal to $45^{\circ},{ }^{\prime} \tau^{\prime}$ is equal to $4.15 \mathrm{MPa}$, as suggested by Narayanan and Darwish [1], and $V_{f}$ is the fibre volume fraction. 


\section{(e) Chinese Guidelines for FRC, CECS 38:2004 [24]}

After a detailed investigation on beams with different grades of concrete and stirrup ratios, the Chinese code [23] has proposed an equation for fiber reinforced concrete

$$
\begin{gathered}
V_{u f}=\frac{1.75}{1+\lambda} f_{t} b d\left(1+\beta_{v} \lambda_{f}\right)+f_{y s t} \frac{A_{s t}}{s} d \\
v_{u f}=\frac{V_{u f}}{b d},
\end{gathered}
$$

where $V_{u f}$ is the shear load of the fiber-reinforced RC member, $\beta_{v}$ is the influence coefficient (taken as 0.75 for crimped fibre) of the steel fibers, $\lambda_{f}$ is a fiber factor that equals to $V_{f}\left(\frac{l_{f}}{d_{f}}\right)$, and $v_{u f}$ is the shear strength of the fiber-reinforced RC member.

Tables $7 \& 8$ show the comparison of experimental results obtained for ultimate shear strength of both non-fibrous and fibrous SCC beams with shear strength models available on vibrated concrete in existing literature.

Table 7: Shear strength values of SCC beams without steel fibers for $6 \mathrm{~mm}$ and $8 \mathrm{~mm} \propto$ of stirrup for various models

\begin{tabular}{|l|c|c|c|c|c|c|c|c|c|c|}
\hline \multirow{2}{*}{ Designation } & \multicolumn{2}{|c|}{$\begin{array}{c}\text { Russo et al. [20] } \\
\mathrm{V}_{\mathrm{u}} \mathrm{MPa}\end{array}$} & \multicolumn{2}{|c|}{$\begin{array}{c}\text { Chinese Code [24] } \\
\mathrm{V}_{\mathrm{u}} \mathrm{MPa}\end{array}$} & $\begin{array}{c}\text { ACI code 318-2014 [25] } \\
\mathrm{V}_{\mathrm{u}} \mathrm{MPa}\end{array}$ & \multicolumn{2}{c|}{ EURO Code-2 [26] } & \multicolumn{2}{c|}{$\begin{array}{c}\text { Experimental } \\
\mathrm{V}_{\mathrm{u}} \mathrm{MPa}\end{array}$} \\
\cline { 2 - 11 } & $6 \mathrm{~mm}$ & $8 \mathrm{~mm}$ & $6 \mathrm{~mm}$ & $8 \mathrm{~mm}$ & $6 \mathrm{~mm}$ & $8 \mathrm{~mm}$ & $6 \mathrm{~mm}$ & $8 \mathrm{~mm}$ & $6 \mathrm{~mm}$ & $8 \mathrm{~mm}$ \\
\hline SCC30-180 & 2.30 & 2.81 & 3.23 & 3.94 & 1.92 & 2.63 & 2.45 & 3.73 & 2.66 & 3.16 \\
\hline SCC70-180 & 4.40 & 4.82 & 4.03 & 4.73 & 2.42 & 3.13 & 3.12 & 4.72 & 3.21 & 4.85 \\
\hline SCC30-360 & 1.97 & 2.23 & 2.78 & 3.13 & 1.46 & 1.82 & 1.83 & 2.27 & 2.41 & 2.80 \\
\hline SCC70-360 & 4.12 & 4.34 & 3.57 & 3.92 & 1.96 & 2.32 & 2.10 & 3.68 & 2.60 & 4.41 \\
\hline
\end{tabular}

From the comparison of the experimental values with the models it can be concluded that the values predicted by Russo et al. [20] and Eurocode-2 [25] are relatively close to the experimental values.

\begin{tabular}{|c|c|c|c|c|c|c|c|c|c|c|c|c|}
\hline \multirow[t]{2}{*}{ Designation } & \multicolumn{2}{|c|}{$\begin{array}{c}\text { Narayanan and } \\
\text { Darwish } \\
{[1]} \\
\text { Vuf } \mathrm{MPa} \\
\end{array}$} & \multicolumn{2}{|c|}{$\begin{array}{c}\text { Ta'an and Feel } \\
{[21]} \\
\text { Vuf } \mathrm{MPa}\end{array}$} & \multicolumn{2}{|c|}{$\begin{array}{c}\text { Swamy et al. } \\
{[22]} \\
\text { Vuf } \mathrm{MPa}\end{array}$} & \multicolumn{2}{|c|}{$\begin{array}{c}\text { Lim and } \mathrm{Oh} \\
{[23]} \\
\text { Vuf } \mathrm{MPa}\end{array}$} & \multicolumn{2}{|c|}{$\begin{array}{c}\text { Chinese code for } \\
\text { FRC } \\
{[24]} \\
\text { Vuf MPa } \\
\end{array}$} & \multicolumn{2}{|c|}{$\begin{array}{c}\text { Experimental } \\
\text { Vuf MPa }\end{array}$} \\
\hline & $6 \mathrm{~mm}$ & $8 \mathrm{~mm}$ & $6 \mathrm{~mm}$ & $8 \mathrm{~mm}$ & $6 \mathrm{~mm}$ & $8 \mathrm{~mm}$ & $6 \mathrm{~mm}$ & $8 \mathrm{~mm}$ & $6 \mathrm{~mm}$ & $8 \mathrm{~mm}$ & $6 \mathrm{~mm}$ & $8 \mathrm{~mm}$ \\
\hline SFSC & 3.22 & 3.73 & 2.81 & 332 & 3.40 & 3.91 & 3.79 & 4.30 & 4.49 & 5.19 & 3.28 & 3.53 \\
\hline SFSCC70-180 & 5.32 & 5.74 & 4.91 & 5.33 & 5.50 & 5.93 & 5.89 & 6.32 & 5.71 & 6.42 & 4.44 & 5.53 \\
\hline SFSCC $30-360$ & 2.89 & 3.14 & 2.48 & 2.74 & 3.08 & 2.23 & 3.47 & 3.72 & 4.03 & 4.38 & 2.84 & 2.80 \\
\hline SFSCC70-360 & 5.04 & 5.25 & 4.63 & 4.85 & 5.23 & 4.34 & 5.62 & 5.83 & 5.25 & 5.61 & 3.86 & 3.98 \\
\hline
\end{tabular}

Table 8: Shear strength values of SCC beams with steel fibers for $6 \mathrm{~mm}$ and $8 \mathrm{~mm} Q$ stirrup for various models 
From the above table it can be noted that the values predicted by Narayanan and Darwish [1] are relatively close to the experimental values.

\section{DETAILS OF TESTED BEAMS}

Of the total 16 beam cast, eight are non-fibrous and eight are fibrous. Figures 10 and 11 show the typical failure patterns of plain and fibrous SCC M30 grade concrete beams.

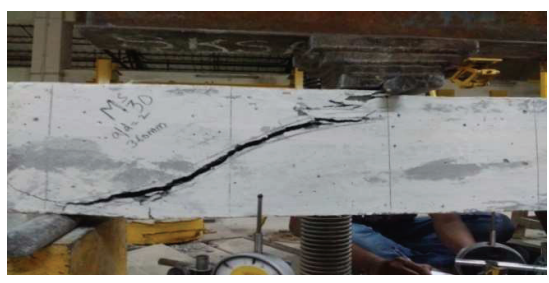

Figure 10 Failure pattern of SCC30

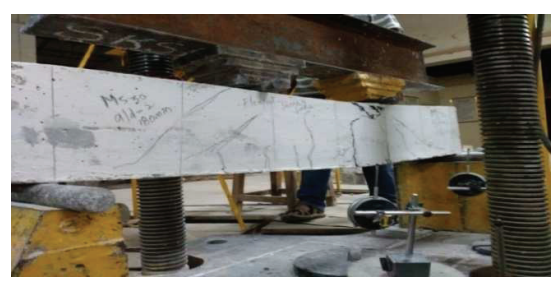

Figure 11 Failure pattern of SFSCC30

Similarly, Figures 12 and 13 show the failure pattern for plain SCC and fibrous SCC for M70 grade concrete. It was noticed that plain specimens failed suddenly with brittle failure, where as in case of fibrous SCC beams the mode of failure was ductile. Influence of fibers is more beneficial in the higher grades of concrete as there are resulting in more brittle fractures.

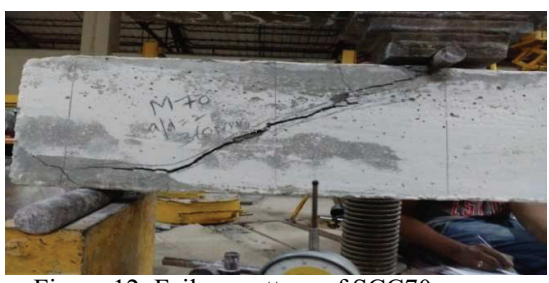

Figure 12: Failure pattern of SCC70

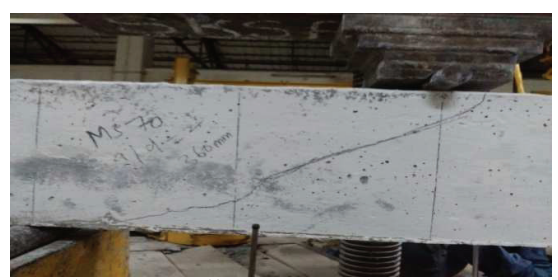

Figure 13: Failure pattern of SFSCC70 


\section{CONCLUSIONS}

Based on this experimental study, the following conclusions have been drawn:

1. Through the use of the rational mix design method, fresh properties for both M30 and M70 grade SCC with fibrous additions could also be achieved, satisfying EFNARC specifications.

2. The addition of fibers enhanced the cracking and ultimate shear strengths by $16 \%$ and $18.9 \%$, respectively. Also, deflections at ultimate load increased by $30.16 \%$, and toughness and stiffness increased by $47.5 \%$ and $15.6 \%$, respectively, for SCC 30 beams with a $6 \mathrm{~mm}$ diameter stirrup.

3. Similarly, the addition of fibers enhanced cracking and ultimate shear strength by $25.71 \%$ and $30.77 \%$, respectively, while deflections at ultimate load increased by $25.5 \%$, and toughness and stiffness increased by $48.65 \%$ and $14.6 \%$, respectively, for SCC 70 beams with a $6 \mathrm{~mm}$ diameter stirrup.

4. Beam SCC $30-180$ with a $6 \mathrm{~mm}$ diameter stirrup showed lower load-carrying capacity compared to beam SCC30-180 with an 8mm diameter stirrup. With an increase in the area of shear reinforcement, shear strength of the beam also increased by $18.8 \%$, and with the addition of steel fibers shear strength increased by $8 \%$. Similar behaviour was observed as the spacing of stirrups increased from $180 \mathrm{~mm}$ to $360 \mathrm{~mm}$.

5. The SCC $70-180$ beam with the $6 \mathrm{~mm}$ diameter stirrup showed lower load-carrying capacity than an identical beam with $8 \mathrm{~mm}$ diameter stirrups. With an increase in the area of shear reinforcement, the ultimate shear strength increased by $68.53 \%$, and a similar trend was observed as the spacing of stirrups increased from $180 \mathrm{~mm}$ to $360 \mathrm{~mm}$. Shear strength increased by $53.07 \%$.

6. A combination of stirrups and steel fibers can reduce the area of shear reinforcement, thereby a lower diameter of stirrup with an inclusion of steel fibers can be utilized with similar behaviour compared to a higher area of shear reinforcement.

7. Comparisons were made of the experimental results obtained from the present study with models available in known literature, and the correlation was satisfactory. 


\section{REFERENCES}

1. Narayanan, R., Darwish, I.Y.S.: Use of steel fibers as shear reinforcement. ACI Structural Journal, 84, 216-227, (1987).

2. Cucchiara C, Mendola LL, Papia M.: Effectiveness of stirrups and steel fibres as shear reinforcement. Cement Concrete Composites, 26, 777-786, (2004).

3. Kwak YK, Eberhard M, Kim WS, Kim J.: "Shear strength of steel fibre-reinforced concrete beams without stirrups". ACI Structural Journal, 99(4), 530-537 (2002).

4. Yining Ding, Zhiguo You and Said Jalali.: "The composite effect of steel fibres and stirrups on the shear behaviour of beams using self-consolidating concrete". Engineering Structures, 33,107-117, (2011).

5. Kim KS, Lee DH, Hwang J H and Kuchma DA.: "Shear behaviour model for steel fiber reinforced concrete members without transverse reinforcements". Engineering Composites, Part B, Elsevier Publications, 43(5), 2324-2334, (2012).

6. Greenough T, Nehdi M.: Shear behaviour of fibre-reinforced self-consolidating concrete slender beams. ACI Material Journal, 105(5), 468-477, (2008).

7. Tiberti G, Minelli F, Plizzari G A and Vecchio F J.: "Influence of concrete strength on crack development in SFRC members". Cement Concrete Composites, 45, 176-185, (2014).

8. Cuenca E, Oviedo E J and Serna P.: "Influence of concrete matrix and type of fiber on the shear behaviour of selfcompacting fiber reinforced concrete beams". Cement and Concrete Composites, Part B, 75, 135-147, (2015).

9. IS: 12269 - 2013: "Indian Standard Ordinary Portland Cement, 53 Grade - Specification", Bureau of Indian Standards, New Delhi, (2013).

10. IS: 3812 (Part-1) - 2003: "Indian Standard Pulverized Fuel Ash - Specification, Part-1: For Use as Pozzolana in Cement, Cement Mortar and Concrete", Bureau of Indian Standards, New Delhi, (2003).

11. IS: 383 - 1970 (Reaffirmed 2002): "Indian Standard Specification for Coarse and Fine Aggregates from Natural Sources for Concrete", Bureau of Indian Standards, New Delhi, (2002).

12. IS: 5388-2003: "Specification for use silica fume as mineral admixture in cement concrete", Bureau of Indian Standards, New Delhi.

13. ASTM C494 / C494M-13: "Standard Specification for Chemical Admixtures for Concrete", ASTM International, West Conshohocken, PA, USA, (2013).

14. ASTM A820-01: "Standard Specification for use Steel Fibers for Fiber-Reinforced Concrete". ASTM International, West Conshohocken, PA, USA, (2001).

15. IS: 1786 - 2008: "Indian Standard High Strength Deformed Steel Bars and Wires for Concrete ReinforcementSpecification”, Bureau of Indian Standards, New Delhi (2008).

16. Tomasz Ponikiewski and Grzegorz Cygan.: "Some properties of self-compacting concretes reinforced with steel fibres", Cement Wapno Beton, 203-209, (2011).

17. S Venkateswara Rao, Seshagiri Rao, D Ramaseshu and P Rathish Kumar.: "Self-Compacting Concrete - A rational mix design", Cement Wapno Beton, CWB-5/2013, pp. 271-280, (2013).

18. EFNARC Specification and Guidelines for Self-compacting Concrete. (2005)

19. IS: 516- 1959 (Reaffirmed 2004): "Indian Standard Methods of Tests for Strength of Concrete", Bureau of Indian Standards, New Delhi, (2006)

20. Russo G, Somma G, Angeli P.: "Design shear strength formula for high strength concrete beams". Material Structural, 37, 680-688, (2004).

21. Ta'an A, Feel A.: Evaluation of shear strength of fibre reinforced concrete beams. Cement Concrete Composites, 12 (2), 87-94, (1990).

22. Swamy RN, Jones R, and Chiam ATP.: "Influence of steel fibres on the shear resistance of lightweight concrete Tbeams". ACI Structural Journal, 90(1), 103-114, (1993).

23. Lim DH, Oh BH.: Experimental and theoretical investigation on the shear of steel fibre reinforced concrete beams. Engineering Structural, 21, 937-944, (1999).

24. China Association for Engineering Construction Standardization: Technical Specification for Fibre Reinforced Concrete Structure, 38, (2004)

25. ACI Committee 318. Building Code Requirements for Structural Concrete (ACI 318-14) and Commentary (318R14): American Concrete Institute; (2014).

26. Eurocode 2 - EN 1992-1-1:2004. Design of Concrete Structures. Part 1: General Rules and Rules for Buildings, IN, Brussels, December 2004, p. 215 


\section{LIST OF FIGURES AND TABLES:}

Figure 1. Details of reinforcement for M30 mix with $\mathrm{a} / \mathrm{d}=2$

Rysunek 1. Szczegóły zbrojenia dla mieszaniny M30 z a/d=2

Figure 2. Details of reinforcement for $M 70 \mathrm{mix}$ with $\mathrm{a} / \mathrm{d}=2$

Rysunek 2. Szczegóły zbrojenia dla mieszaniny $\mathrm{M} 70 \mathrm{z}$ a/d $=2$

Figure 3. some tests on workability of SCC

Rysunek 3. Wybrane badania obrabialności SCC

Figure 4. Shear Strength vs stirrup diameter for $180 \mathrm{~mm}$ spacing

Rysunek 4. Wytrzymałość na ścinanie a średnica strzemienia dla rozstawu $180 \mathrm{~mm}$

Figure 5. Shear Strength vs stirrup diameter for $360 \mathrm{~mm}$ spacing

Rysunek 5. Wytrzymałość na ścinanie a średnica strzemienia dla rozstawu $360 \mathrm{~mm}$

Figure 6: Toughness vs. stirrup spacing for $6 \mathrm{~mm} \otimes$ stirrup

Rysunek 6. Wytrzymałość a rozstaw dla strzemienia o średnicy $6 \mathrm{~mm}$

Figure 7. Toughness vs stirrup Spacing for $8 \mathrm{~mm} \propto$ stirrup

Rysunek 7. Wytrzymałość a rozstaw dla strzemienia o średnicy $8 \mathrm{~mm}$

Figure 8(a). Load Vs Deflections for SCC 30; 8mm Q Stirrup

Rysunek 8(a). Obciążenie a ugięcia dla SCC 30; strzemię o średnicy 8mm

Figure 8(b). Load Vs Deflections for SCC 30; 6mm $\propto$ Stirrup

Rysunek 8(b). Obciążenie a ugięcia dla SCC 30; strzemię o średnicy 6mm

Figure 9(a). Load Vs Deflections for SCC 70; 8mm $\propto$ Stirrup

Rysunek 9(a). Obciążenie a ugięcia dla SCC 70; strzemię o średnicy 8mm

Figure 9(b). Load Vs Deflections for SCC 70; 6mm $\propto$ Stirrup

Rysunek 9(b). Obciążenie a ugięcia dla SCC 70; strzemię o średnicy 6mm

Figure 10. Failure pattern of SCC30

Rysunek 10. Schemat błędu SCC30

Figure 11. Failure pattern of SFSCC30

Rysunek 11. Schemat błędu SFSCC30

Figure 12. Failure pattern of SCC70

Rysunek 12. Schemat błędu SCC70

Figure 13. Failure pattern of SFSCC70

Rysunek 13. Schemat błędu SFSCC70

Table 1. Details of beams

Tabela 1. Szczegółowe informacje na temat belek 
Table 2. Mix proportions of M30 and M70 grade SCC

Tabela 2. Proporcje mieszaniny SCC klasy M30 i M70

Table 3. Fresh properties of M30 and M70 grade SCC without and with fiber

Tabela 3. Właściwości świeżości SCC klasy M30 i M70 bez i z włóknem

Table 4. Hardened properties of M30 and M70 grades of SCC at 28 days

Tabela 4. Właściwości utwardzania SCC klasy M30 i M70 podczas 28 dni

Table 5. Initial crack strength, Ultimate shear strength, Toughness and Stiffness for $\mathrm{a} / \mathrm{d}=2$ for $6 \mathrm{~mm} \otimes$ stirrups

Tabela 5. Początkowa wytrzymałość na pękanie, maksymalna wytrzymałość na ścinanie, wytrzymałość i sztywność dla strzemion o średnicy $6 \mathrm{~mm}, \mathrm{a} / \mathrm{d}=2$

Table 6. Initial crack strength, Ultimate shear strength, Toughness and Stiffness for $\mathrm{a} / \mathrm{d}=2$ for $8 \mathrm{~mm} \otimes$ stirrups

Tabela 6. Początkowa wytrzymałość na pękanie, maksymalna wytrzymałość na ścinanie, wytrzymałość 1 sztywność dla strzemion o średnicy $8 \mathrm{~mm}, \mathrm{a} / \mathrm{d}=2$

Table 7. Shear strength values of SCC beams without Fiber for $6 \mathrm{~mm}$ and $8 \mathrm{~mm} \otimes$ of stirrup for various models Tabela 7. Wartości wytrzymałości na ścinanie belek SCC bez włókna dla strzemienia o średnicy $6 \mathrm{~mm}$ i $8 \mathrm{~mm}$ dla różnych modeli

Table 8. Shear strength values of SCC beams with steel fibers for $6 \mathrm{~mm}$ and $8 \mathrm{~mm} \otimes$ stirrup for various models Tabela 8. Wartości wytrzymałości na ścinanie belek SCC z włóknami stalowymi dla strzemienia o średnicy 6 $\mathrm{mm}$ i $8 \mathrm{~mm}$ dla różnych modeli 


\section{HYBRYDOWY WPLYW STOSUNKU STRZEMION I WLÓKIEN STALOWYCH NA ŚCINANIE BETONU SAMOZAGĘSZCZALNEGO}

Slowa kluczowe: beton samozagęszczalny, ścinanie, beton zbrojony (RC), ścinanie spowodowane zginaniem.

\section{STRESZCZENIE:}

Spośród wszystkich rodzajów uszkodzeń betonu, ścinanie jest nagłe i kruche i pojawia się gwałtownie, bez ostrzeżenia. Aby uniknąć tego rodzaju problemów z betonem, belki są tradycyjnie wzmacniane za pomocą strzemion, w bliższej odległości od konstrukcji. Ograniczone rozmieszczenie prętów zbrojeniowych i strzemion na elementach wykonanych z betonu zbrojonego (RC), takich jak słupy, belki i płyty, utrudnia zagęszczanie betonu w każdym miejscu w szalunku za pomocą wibratorów mechanicznych. Pustki i makropory wewnątrz betonu powstają w wyniku nieodpowiednich drgań, a zatem zagęszczenie może wpływać na wytrzymałość mechaniczną i trwałość betonu, a także stać się możliwą przyczyną pogorszenia jego jakości.

Beton konwencjonalny stosowany w budownictwie i inżynierii lądowej wymaga zagęszczania w celu uzyskania wytrzymałości, trwałości i konsystencji. Ta klasyczna metoda zagęszczania i drgań powoduje zakłócenia i dodatkowe koszty dla projektów, a ponadto stanowi poważne zagrożenie dla zdrowia na i w okolicach placu budowy. Beton samozagęszczalny (SCC), jak sama nazwa wskazuje, nie wymaga zewnętrznego wysiłku przy zagęszczaniu. Jest to dobrze przemyślane rozwiązanie, mające na celu pozbycie się powyższego problemu. Ze względu na wyżej opisaną właściwość, nie potrzeba drgań, a więc nie powstają również zanieczyszczenia hałasem, zmniejszają się koszty robocizny i beton może być zagęszczany w każdym miejscu szalunku, bez jakiejkolwiek znaczącej segregacji, przeważnie w zatkanych wzmocnieniach.

W niniejszej pracy przedstawiono charakterystykę pękania przy ścinaniu włóknistego betonu samozagęszczalnego o normalnym i wysokim stopniu wytrzymałości (M30 i M70). W niniejszej pracy zastosowano dwie średnice strzemion (6 $\mathrm{mm}$ i $8 \mathrm{~mm}$ ) o stałej zawartości włókien stalowych wynoszącej $38 \mathrm{~kg} / \mathrm{m}^{3}$ ( $0.5 \%$ objętości betonu). Rozmiar belki został ustalony na 100 x 200 x $1200 \mathrm{~mm}$. Przez cały okres trwania badania utrzymywano wyraźny rozstaw belek wynoszący 1100 $\mathrm{mm}$. Łącznie zbadano 16 belek z niedostatnim ścinaniem przy obciążeniu trzypunktowym. Dwa rozstawy strzemion (180 mm i $360 \mathrm{~mm})$ są stosowane dla stosunku ścinania do głębokości $(\mathrm{a} / \mathrm{d}=2)$. Badanie wykazało, że początkowe obciążenie przy pękaniu oraz końcowe obciążenie wzrosły wraz ze wzrostem średnicy strzemienia. Zauważono również, że tryb awaryjny zmienił się z kruchego ścinania na ścinanie spowodowane zginaniem przy obecności włókien. Zachowanie mechaniczne SFRSCC uległo poprawie w wyniku połączonego efektu działania strzemion i włókien stalowych. Sztywność, wytrzymałość i ugięcie belek wzrosły w porównaniu do belek SCC bez włókien. Wyniki eksperymentalne zostały porównane z istniejącymi modelami dostępnymi w literaturze, a korelacja okazała się być zadowalająca. 